Otterbein University

Digital Commons @ Otterbein

Business, Accounting and Economics Faculty Scholarship

$9-2013$

\title{
Education Par Excellence: Developing Personal Competencies and Character Through Philanthropy-based Education
}

Shirine L. Mafı

Otterbein University

Marsha Huber

Youngstown State University

Follow this and additional works at: https://digitalcommons.otterbein.edu/bus_fac

Part of the Accounting Commons, Education Commons, and the Nonprofit Administration and Management Commons

\section{Repository Citation}

Mafi, Shirine L. and Huber, Marsha, "Education Par Excellence: Developing Personal Competencies and Character Through Philanthropy-based Education" (2013). Business, Accounting and Economics Faculty Scholarship. 2.

https://digitalcommons.otterbein.edu/bus_fac/2

This Article is brought to you for free and open access by the Business, Accounting and Economics at Digital Commons @ Otterbein. It has been accepted for inclusion in Business, Accounting and Economics Faculty Scholarship by an authorized administrator of Digital Commons @ Otterbein. For more information, please contact digitalcommons07@otterbein.edu. 
Education par excellence: Developing personal competencies and character through philanthropy-based education

\author{
Marsha Huber, Ph.D., CPA* \\ Williamson College of Business Administration \\ Youngstown State University \\ One University Plaza \\ Youngstown, $\mathrm{OH} 44555$, USA \\ Email: mmhuber@ysu.edu \\ Phone: +1 6144061159 \\ Fax: +1 7409658786
}

\author{
Shirine L. Mafi, Ph.D. \\ Department of Business, Accounting, and Economics \\ Otterbein University \\ One South Grove \\ Westerville, $\mathrm{OH}$ 43081, USA \\ Email:smafi@otterbein.edu \\ Phone: +1 6148231796 \\ Fax: +1 6148231014
}

*Corresponding Author 


\section{ABSTRACT}

This teaching note presents an innovation in accounting education called the Philanthropy Project. ${ }^{1}$ The Philanthropy Project emphasizes experiential learning and is designed to promote the learning of discipline-specific concepts while simultaneously addressing the social needs of the surrounding community. In the Philanthropy Project, students receive money to distribute to not-for-profit organizations (NFPs) based on a competitive proposal process they help to develop and administer. A distinguishing characteristic of this project is that it is not a simulation.

Students make real decisions that have immediate consequences to certain groups of people in their own communities. They have to make difficult choices by allocating scarce resources to some agencies and saying "no" to other agencies, all with worthy causes.

The philanthropy project was administered in two introductory financial accounting classes, one at University A (a regional public university) and one at University B (a comprehensive private university). At the conclusion of the project, students reported experiencing the benefits of collaboration, communication, conceptual learning, community engagement, and character development. In addition to learning typical for-profit accounting topics, students participating in the philanthropy project also learned about NFP financial statements and related economic measures. Given the specified not-for-profit context, this project could be relevant for governmental and not-for-profit accounting classes. A timeline of activities, grading rubric, and templates are provided to aid in the adoption of this project by other accounting educators.

Keywords:

Service-learning

Philanthropy

Community engagement

\footnotetext{
${ }^{1}$ The Philanthropy Project won the 2011 Howard Theall Innovation in Accounting Education award from the Canadian Academic Accounting Association (CAAA). This project also received an honorable mention from the American Accounting Association for the 2009 Bea Sanders/AICPA Innovation in Accounting Education Award. 
AICPA personal competencies

Not-for-profit (NFP) accounting education 


\section{Introduction}

When it comes to the topic of the adequacy of accounting education, most accounting educators agree change is needed. Where the agreement usually ends, however, is on "How?" While some are convinced that new "experiential learning" models are needed, others maintain that the older "test-and-drill" model is still the most effective way of teaching (Blanthorne, et al., 2005; Francisco, et al., 2003). Recent thinking, however, seems to favor the newer experiential learning model. In Charting a National Strategy for the Next Generation of Accountants, the Pathways Commission writes, "Students in accounting classes are exposed to technical material in a vocation-focused way that is disembodied from the complex, real-world setting to which the students are bound" (Pathways Commission, 2012, 11). Based on the Pathways Commission's assessment, accounting educators are encouraged to develop experiential learning experiences to enhance their courses.

Professional organizations also beckon educators to create a curriculum that not only develops professional skills but also cultivates character (Fontaine, 2012; Davis \& McLaughlin, 2009; AICPA, 2008). For example, the American Institute of Certified Public Accountants (AICPA) classifies core educational competency areas as functional, personal, and broad-based (AICPA, 2005). Personal competencies include soft skills development in personal demeanor, decision-making, interaction, and communication skills. "Individuals entering the accounting profession should behave in a manner that is consistent with the character and standards of the discipline of accounting ... This competency involves demonstrating objectivity, integrity, and ethical behavior" (AICPA, 2005). Former SEC Commissioner Harvey Goldschmid further illustrates this point by stating, "We can hire all kinds of bright minds but human character is fundamental to making the whole system work" (Niemotko, 2003, 26). 
In response to the call for experiential learning and character development, the authors present a real-world learning experience called the Philanthropy Project. Accounting students serve as board members to distribute money to NFPs based on a competitive proposal process they help to develop and administer. Students are given two restrictions: (1) they must be deliberate in their decision-making process and justify their decisions, and (2) some NFPs must be denied funding.

This teaching note is organized into four sections. First, the authors briefly examine relevant literature about philanthropy and the history of service learning in accounting education. Second, they provide step-by-step instructions on how to implement the Philanthropy Project in an accounting class. Third, the authors present preliminary evidence supporting the efficacy of this project. Fourth, the appendices provide materials to support the successful adoption of the Philanthropy Project in different accounting contexts.

\section{Philanthropy-based education}

Philanthropy consists of the voluntary giving of time, money, and resources to benefit others or society without regard to personal gains (Seifert, et al., 2004). In the past, businesses mainly focused philanthropic activities on various executives' or founders' areas of interest such as the arts, neighborhood revitalization, or education. Over the last few years, however, philanthropy's role in business has evolved into a strategic role (e.g. creating goodwill with the public) and has the potential to serve a similar role in accounting education (La Cour \& Kromann, 2011).

\subsection{Philanthropy in business}

Of course, neither corporate charitable giving nor philanthropy is new. Companies have given to charity as a way to meet social obligations for years, and almost all measures of corporate social responsibility include philanthropic giving as a component (Porter \& Kramer, 
2002). What is changing, however, is the traditional view of the firm. Maximizing profits is no longer the only objective for some shareholders who believe firms also have a responsibility to society as a whole (Mass \& Liket, 2011). While some argue that philanthropy is simply "window dressing" serving as another business tool to increase the bottom line via creating goodwill with stakeholders (Koehn \& Ueng, 2010), others believe philanthropy is a socially responsible action. In fact, corporate philanthropic giving has been on the rise, totaling $\$ 22.83$ billion in 2010 -an increase of 10.6\% over 2009 (Wiley Periodicals, Inc., 2011).

Since corporations and accounting firms use philanthropy to create goodwill with clients and the community (Porter \& Kramer, 2002), asking accounting students to engage in philanthropy is a type of experiential learning. The Philanthropy Project provides a vehicle for students to learn about NFPs and develop character as they hone personal competencies.

\subsection{Philanthropy in education}

Significant decreases in civic engagement in the U.S. have prompted higher education institutions to embark on several approaches to strengthen civic education (Nishishiba et al., 2005). Perry (2005) found three variables affecting students' civic engagement-community efficacy, attitudes about citizen control of government, and attitudes toward diversity. Philanthropy in education promotes civic engagement by encouraging conversations and relationships among citizens to build a "more reflective and resourceful local communities" (Lynn \& Wisely, 2006, 5).

Certain educators maintain that philanthropy develops desirable educational outcomes.

For example, in a review of the literature on student philanthropy, Olberling (2009) identified five reasons to add philanthropy projects to college courses:

1) to enhance student awareness of social problems and NFPs in the community,

2) to influence student attitudes, interests, intentions and behaviors related to civic engagement and social responsibility, 
3) to increase student knowledge of philanthropic processes, such as grant seeking and grant making,

4) to improve student understanding of the course content by integrating theory and practice, and

5) to enhance student critical thinking, communication, and leadership skills.

Since philanthropy projects are thought to increase awareness of social problems, a student's desire to engage in philanthropy may also increase later in life after graduation. Equally important, Millisor and Olberling (2009) report that the philanthropy component of a course can help students learn course content better as they applied the course principles to practice.

Philanthropy projects have been used at 43 different colleges and universities and incorporated into a variety of disciplines such as public administration, business (including management and marketing), communication, social work, English, psychology, criminal justice, economics, education, philosophy and theater (Millisor \& Olberling, 2009). Integrating the project with course objectives is what makes the project unique for each discipline. For example, students in a psychology class related their service experience to the basic psychological processes of human development and motivation (Smith \& O'Loughlin-Brooks, 2011). Students in a management class conducted a SWOT analysis for the organizations they invited into the request for proposals (RFP) process. In each of these cases, when integrating the project with course objectives, the project is believed to become a more relevant learning experience for students.

\subsection{Roots in service learning}

Philanthropy-based education has its roots in service learning, which may have many positive learning outcomes. Evidence suggests that service learning can be used to improve standardized test performance, attendance, retention, grades, motivation, and engagement (Eyler \& Giles, 1999; ' '...”, et al., 2012). Service learning may also help students make connections 
between theory and practice as students apply critical thinking and problem-solving skills to community needs (Cruz, 2001; Rama, 1998a).

Service learning is believed to foster an ethic of service by changing students' worldviews - taking them from the single-minded pursuit of profit to think critically about the impact of business decisions upon external stakeholders (Vega, 2007; Hardie, et al., 2011). Kielsmeir (2011) reported that service learning promotes the view that all people in a democratic society are citizens with the capacity to contribute regardless of income, education, ethnicity, gender, or physical and mental challenges. Furthermore, service learning activities may lead to subsequent positive effects on the surrounding neighborhood and schools (Kahne \& Sporte, 2008; Astin \& Sax, 1998; Mabry, 1998; Boss, 1994; Eyler, et al., 2000; Waterman, 1997). When engaged in community service, evidence suggests that students gain a greater appreciation of their own discipline as well as experiencing an increased sense of civic duty (Bringle \& Hatcher, 1995).

Finally, service learning may contribute to the development of personal competencies. Service learning has been believed to help students improve their self-esteem and self-efficacy, allowing for a smoother transition to adulthood and higher leadership capacity (Yates \& Youniss, 1996; Astin, et al., 2000). Service learning is also thought to improve life skill development, social responsibility, communication skills, moral reasoning, life-long learning, and tolerance (Boss, 1994; Giles \& Eyler, 1994; Rama, 1998b; Bringle \& Hatcher, 1995; Tucker \& McCarthy, 1998; Eyler \& Giles, 1999; Martin, et al., 2006).

\subsection{Accounting literature}

Service learning has a rich history in accounting education. Most service learning work has been directed to help those less fortunate. The most widely used service-learning project in accounting is probably the Volunteer Income Taxpayer Assistance program (VITA) where students prepare income tax returns for low-income taxpayers (Carr, 1998; Milani, 1998; 
Oestreich, et al., 1998; Strupeck \& Whitten, 2004). Other examples include workshops where accounting students teach business literacy to at-risk youth or to the homeless (DeBerg, 1998; Pringle, 1998). In addition, students in upper-level accounting classes have helped small businesses and NFPs improve their accounting systems, internal control practices, budget development, and cost management (Michenzi, 1998; Ravenscroft, 1998; Lenk, 1998; Woolley, 1998; Gujarathi \& McQuade, 2002; Still \& Clayton, 2004; Rose, et al., 2005; Zamora, 2012).

Service learning in accounting is believed to have similar benefits to those reported in the general higher education literature. For example, Cruz (2001) and Chiang (2008) found that accounting students experienced an improved learning of accounting concepts and increased respect for the discipline of accounting as a result of community involvement. In addition, Stukas, et al., (1999) discovered that students involved in VITA showed significantly higher intention to participate in all types of pro bono activities, not just in those activities with which they were familiar. Furthermore, Clavert and Kurji (2012) purport service-learning can develop skills such as project management, team communication, and ease in client interactions when engaged in an unstructured environment where confidentiality and client management is required.

Some faculty members, however, reported negatives when implementing service learning in accounting. A number of students complained about mandated participation, leaving them untouched by the experience (DeBerg, 1998; McPhail, 2005). In addition, faculty members have reported difficulty with the following aspects of service learning: finding partners, assessment, grading, scheduling, and time management (Carr, 1998; Lenk, 1998; Pringle, 1998; Tschopp, 2004; Still \& Clayton, 2004; Chiang, 2008). Because of these issues, the authors of this paper provide implementation guidelines such as a timeline of activities, grading rubric, and templates in the appendices to support the successful adoption of the Philanthropy Project in different accounting educational contexts. 


\section{The philanthropy project}

In the past, service learning has served as the primary academic vehicle to educate accountants in matters "of the soul." The Philanthropy Project provides another vehicle to "develop the soul" serving as the first philanthropy-based education case in accounting. This project uses a pedagogical model that intentionally integrates academic learning and philanthropy. The difference between service learning and philanthropy-based education is its decision-making component.

In the typical accounting service-learning experience, students volunteer time or give recommendations to individuals, companies, or NFPs. In the Philanthropy Project, students give money to NFPs based on a competitive proposal process that they help to develop and administer. In other words, accounting students act similarly to members of the Board of Directors for foundations - issuing an RFP, analyzing and ranking submitted proposals, and deciding which proposals to fund and how much to fund. ${ }^{2}$ During the selection process, students must justify their decisions and deny some NFPs funding, forcing students to make decisions regarding resource allocation.

Integrating the Philanthropy Project with course objectives is a way to create a relevant and unique learning experience. In the two introductory financial accounting classes, the philanthropy accounting project was taught in conjunction with the financial statement analysis chapter. Instead of only analyzing traditional for-profit statements, students were introduced to NFP statements as well. Students noted the similarities and differences when compared to forprofit statements and learned about financial indicators used in the not-for-profit sector. Students were also exposed to budgets for the first time, seeing how their contributions would be spent.

\footnotetext{
${ }^{2}$ The accounting classes included Principles of Financial Accounting offered once at each of two universities. University $A$ is a private Midwestern comprehensive university with 3,000 students. University B is a public Midwestern university with 13,500 students. Funding, received from the Ohio Campus Compact and local philanthropists, was $\$ 4,000$ at University $A$ and $\$ 500$ at University B.
} 
Depending on the pace of the course, the project takes about 6-10 weeks to complete. If the instructor teaches in the quarter system, the timeline is tight. Faculty using the project the first time may (or, are likely to) experience a certain level of added stress until they become familiar with the process. Our primary recommendations for instructor success are: (1) assimilate the philanthropy project with the course objectives, (2) do as much work before the course begins as possible, (3) get a volunteer or graduate assistant to help administer the project, and (4) adhere to the suggested timeline (Appendix A).

To provide support in the administration of the project, the authors recommend recruiting volunteers to help with the administration of the project. These volunteers provide guidance to the teams, keep them on task, and help teams interpret the financial statements submitted during the proposal process. At both Universities A and B, intermediate accounting students and graduate assistants served as volunteers.

\subsection{Step-by-step guidelines}

Following are instructions on how to best integrate the Philanthropy Project in an accounting class (with references to supporting forms and templates). First, a Quick Start Checklist summarizing the steps of the project is provided (Table 1). Appendices and templates are also provided for support at the conclusion of this teaching note. Appendix A presents a suggested timeline of activities. Appendix B includes a grading rubric that can be used to score a student's participation throughout the entire proposal process. Finally, Appendix C provides templates for each step of project. $^{3}$

\footnotetext{
${ }^{3}$ The authors recommend faculty members adopt the provided templates and scoring rubrics and edit them to fit their own class learning objectives. Microsoft Word copies of the templates are available upon request.
} 


\section{Table 1}

Quick start checklist

\section{For Professors}

1) Locate funding sources (internally and externally).

2) Identify a list of NFP organizations.

3) Adapt philanthropy project to course objectives.

4) Manage the weekly activities and keep to the timeline.

5) Determine assessment methods.

\section{For Students}

1) Form teams with 4 or 5 students.

2) Select NFPs you are interested in contacting.

3) Contact the NFP to find out if the organization in question is willing to participate in the process.

4) Gather materials for each NFP and post to a collaborative website.

5) Each team narrows selection to 1 or 2 agencies.

6) Review evaluation criteria for RPFs.

7) Invite NFPs to submit proposals.

8) Review the criteria for scoring the proposals and rank them accordingly.

9) Invite "top scoring" organizations in for a presentation.

10) Decide on the winners and amount of awards.

Step 1: Identifying NFPs. The project begins with students joining teams of 4-5 members united principally by their passion for a particular social cause. Students identify areas of general philanthropic interest such as children and youth programs, neighborhood revitalization efforts, or needs related to hunger, homelessness, or health issues. Alternatively, the instructor could present teams with a list of NFPs that have agreed to participate in the RFP process. At University A, the Center for Community Engagement created a list of NFP partners that students could contact.

Step 2: Gathering Data. Next teams narrow their list to 4 or 5 NFPs (one per team member), and proceed to gather data on each of them. Information and documents are shared on 
wiki (or collaborative website); other systems, such as Blackboard or Google Docs, provide similar functionality. Students add the organization's mission, key donors, a link to its website, and contact information to the collaborative website (Template 1). Students also confirm with organizations that they will submit a proposal if invited to do so.

Step 3: The Selection Process. Students then review the proposed guidelines for RFPs and suggest changes to make the list more applicable for their own class (Template 2). As the class progresses, each team is asked to narrow the selection process to 1 or 2 agencies, inviting agency to submit a proposal. The instructor sends an e-mail to each agency with the proposal guidelines and due dates for submitting the grant application (Template 3). Once received, proposals are posted on the collaborative website for student review. Students participate in the proposalselection process over the next two classes.

In the first of these two class sessions, students discuss the applications. Before the next class, students individually score each proposal using a rating sheet (Template 4). During the second class session, students conduct a tallying of their ratings on a spreadsheet that is projected on a screen. Students narrow the selection process to $2-3$ organizations and invite representatives from the NFP to present to the class (or in some cases, to go on a site visit).

Step 4: NFP Presentations and Vote. Finalists, determined on the basis of a class rating and vote, are invited to present their proposals to the class. In some cases, students ask organizations to discuss certain aspects of their proposal. For instance, the financial accounting classes in which we used the project asked organizations to discuss their financial statements, budget, and the economic impact of the grant on the local community. After the presentations, students deliberated on the allocation of funds based on their group scoring of the presentations (Template 5). Subsequently, the faculty member sends letters to the NFPs notifying them of their 
award status (Templates 6 and 7). At the conclusion of the course, students celebrate this learning experience at an award ceremony, either on campus or at an event hosted by the grantee.

Step 5: Reflection. After the final vote, students write about their learning experience in a reflection paper and submit scores for team members' contributions to the project (Template 8).

\subsection{Context}

As noted above, the Philanthropy Project was conducted at one private (University A) and one public university (University B) with traditionally-aged students. Although it was used in introductory financial accounting, this project can be adapted for use in other accounting classes or for use in a stand-alone class. For example, the project was adapted by one of the authors for an auditing class with teams selecting one NFP to consult with. Students conducted a site visit and completed an internal control questionnaire. In addition, each team wrote a letter to the organization outlining internal control deficiencies. Since students study NFP financial statements and serve as board members, the authors believe this project could be readily adopted to meet the objectives for a government and not-for-profit accounting course.

The Philanthropy Project has only been used in smaller accounting classes. At University A, the financial accounting class had 25 sophomores and at University B the class had 18 students, with both classes having a mix of business and accounting majors. Philanthropy projects, however, have been successfully used in a variety of non-accounting classes with larger enrollments. For example, at Northern Kentucky University, the typical course with a philanthropy project had 50 students enrolled (Millisor \& Olberding, 2009).

\subsection{Challenges}

The Philanthropy Project has it challenges. First, students may need guidance on locating NFPs for the project. If the university has a Center for Community Engagement, a list of local 
NFPs might be available (as in the case at University A). Since University B was a commuter campus, students were familiar with many of the local NFPs and were able to generate their own list. In another rendering of philanthropy, University B used another approach to recruit proposals for non-accounting classes. The Director of the Center for Non Profit Leadership issued an RFP to the surrounding community through local media outlets, requesting proposals be sent to her office. She then forwarded proposals to classes based on their expressed philanthropic interests.

Second, since the project uses class time, instructors must decide what content to keep in and what content to leave out of the course. As Albrecht and Sack noted, "Our educational models focus too much on content at the expense of skill development—skills our students need to be successful professionals" (Albrecht \& Sack, 2000, 43). Thus, the authors do not apologize for making room for the Philanthropy Project in their classes. One way to decrease the project time requirements, however, is for instructors to complete all five steps in Table 1 before the beginning of the term, including contacting NFPs. If this is done, students can then at the start of the term commence the process at Step 4 on Table 1.

Third, funding must be obtained. As noted earlier, funding for the projects discussed in this paper ranged from $\$ 500$ to $\$ 4,000$, depending on the availability of funds. The Campus Compact organization, ${ }^{4}$ local philanthropists, the authors, and the colleges provided funding to support the use of the project at each of our institutions. Also noteworthy is how funding levels can impact NFP participation. For example, when funding at the $\$ 4,000$ level, the class contacted ten organizations, five submitted proposals, and three were funded. When funding was at the $\$ 500$ level, five organizations were contacted, three organizations submitted proposals, and one was

\footnotetext{
${ }^{4}$ Campus Compact is a national coalition of 1,200 higher education presidents who are committed to fulfilling the civic purposes of higher education. The organization provided seed money for the first iteration of this project.
} 
funded. Higher funding levels will likely draw the interest of more NFPs; even so, smaller NFPs reported that even $\$ 500$ served as a meaningful contribution.

A few institutions have developed sustainable ways to fund philanthropy projects. With the approval of university administrators, student activities funds have been utilized. One psychology department used royalties collected from self-published lab manuals as a funding source (Smith \& O’Loughlin-Brooks, 2011). On occasion, foundations contribute to philanthropy projects (e.g., the Mayerson Foundation in Cincinnati funds philanthropy in education). Finally, there is a philanthropy model that does not require external funding because students evaluate existing proposals for an existing foundation (Olberding, 2009). This indirect approach requires a partnership between the faculty member and the foundation, but streamlines the entire process since the foundation already has proposals. Furthermore, the indirect approach requires less startup time from students since they start the process at Step 6 on Table 1.

\section{Evidence of project efficacy}

Regarding overall project efficacy, the authors offer both quantitative and qualitative data showing positive outcomes. At Universities A and B, written comments from student participants were collected on reflection papers. At University B, a satisfaction survey was administered at the conclusion of the project.

\subsection{Qualitative analysis}

In a qualitative assessment, evidence (in the form of student perceptions) suggests that the Philanthropy Project develops both the character and personal competencies of accounting students. Five themes emerged from the analysis of student comments. The authors believe the Philanthropy Project enhances community engagement, collaboration and communication, conceptual learning, critical thinking, and character development. Following is a discussion about each of these educational dimensions. 
Community engagement -During the organizations' presentations, students heard from the executive directors of participating social organizations. Students observed a different kind of leader, one who appeared to be driven by intrinsic motivation (e.g., passion) rather than extrinsic motivation (e.g., money). Students also learned about diverse populations with diverse needs. In one class, students discovered that one in six families in the community lived below the poverty level.

The authors enjoyed observing students become passionate about their civic duties. The organizations' presentations touched many students with some even moved to tears. Students commented on their renewed appreciation of their own lives as they learned from the lives of others who were less fortunate. Following are selected student comments:

"I am definitely volunteering from now on. This was a very emotional project. Meeting one of the kids made me work harder..."

"It got us engaged. It made us feel like we were accomplishing something great."

"It made me want to become more involved with not for profit agencies. It helped me see that there are always people that need help."

Conceptual learning - Students were introduced to the financial statements of the not-forprofit sector. They also evaluated budgets that were submitted with the grant proposals. One class learned that being a NFP did not necessarily equate to being "poor" as students noted one NFP agency had a million dollars in its checking account.

As students heard Executive Directors tell stories of their struggles, they learned of the constraints that many NFPs face where funding and staffs are limited. Students also heard about NFP organizations' victories, such as how one small local NFP agency brought over a million dollars' worth of new jobs into the local economy. Finally, students were introduced to the NFP sector as a field of possible employment. Supporting student comments included: 
"The process of assessment allowed me to gain a better understanding of how not-forprofits work by studying their financials."

"I learned the different names of the financial statements of not-for-profit agencies. I learned how they function and their methods of funding. I was able to relate what I learned in the course to an actual case."

I learned 'the 'ins' and 'outs' of organizations as far as money. Where it's going, how it's being used and who it's actually going to benefit."

Collaboration and communication-Students worked together as teams throughout the term to gather information, invite NFPs to participate, and in group decision-making. Students were required to call their organizations and locate a decision-maker to find out if the organization was willing to submit a proposal. Teams also collaborated in deciding which organizations to move forward in the process and to ultimately fund. Supporting student comments include the following

"I learned how to better work with others, and how despite your differences in opinion, you can still come to a solid conclusion."

"Not all agencies use your money for what you think they should. Many different opinions arose from these presentations."

"Through group collaboration we were allowed to decide which organizations would profit from our contribution. The presentations by the not-for-profit organizations made us aware of how our donation would be used and provided a personal connection to those who benefit from the money."


team members. When it came to allocating scarce resources, students discussed which organizations to fund and why. In one case, the authors observed students discussing whether an animal shelter should take precedence over funding for human needs. In another situation, after reviewing the financial statements for one large NFP, students decided to fund a smaller agency where they perceived that funding would have a greater impact.

This project also seemed to help students understand the importance of quality grant writing and presenting. For example, students rejected organizations whose applications were not 
filled out properly (giving them a first-hand understanding of how important it is to follow instructions). Supporting student comments include the following:

The project "allows us to see what funders expect and how to improve the quality of our own grant proposals in the future."

"I learned that when you are offering a donation to a company sometimes knowing too much can sway decision making skill. Also it is important for a company to come prepared with information such as visual aids rather than just speak from a piece of paper about what they do."

"It was a valuable community service tool for students to learn about local organizations and put some analytic thought into how to best select a charity for donation. This is often an afterthought for non-major donors."

Character building-The project was designed to have students take ownership and display pride in their participation in the project. Many students commented how they learned that one person can make a major difference in the surrounding community. Other students indicated to the authors that they planned to participate in philanthropy in the future. Supporting student comments include the following:

"We can all make a difference in the world. It is not someone else's job. We are all responsible for our world.”

"It was great to see how we could make a difference in these small organizations. I was happy to see how all of us could have a big influence on the lives of those who need help the most."

"This is great! It helped everyone get a taste of how philanthropy projects can enrich your life."

The authors believe the Philanthropy Project offers an experience that is humanitarian, engaging, experiential, and unique. Based on the thematic qualitative analysis of student comments, the authors created an illustration (Figure 1) to portray what can be considered the five "Cs" of philanthropy-based education: community engagement, conceptual learning, critical thinking, collaboration and communication, and character building. 




Fig. 1

The five "Cs" of philanthropy-based education

\subsection{Quantitative analysis}

In conjunction with the offering of the project at University $\mathrm{B}$, the authors also

administered a satisfaction survey (Table 2). Students responded on a 5-point Likert-type scale

(1=strongly disagree; $5=$ strongly agree). With a $78 \%$ response rate, students of traditional age,

$50 \%$ male, reacted favorably to the project (all items averaged 4.07). When asked if "the

instructor should continue to use the project in the future," the mean response was $4.21 .^{5}$

\footnotetext{
${ }^{5}$ The Ohio Campus Compact administered a survey when this project was conducted in the auditing class at University B referenced earlier in the paper $(n=13)$. The organization asked students "How likely they were to do the following?" Students responded on a Likert-type scale ( $1=$ not at all likely; 2 = somewhat likely; 3 = pretty likely; and $4=$ very likely). The self-reported pre and post-test scores significantly increased in four areas: planning to donate (2.14 to 2.43), developing a budget to give (2.05 to 2.50), talking to peers about giving (2.0 to 2.43), and believing that individuals have a responsibility to help those in need (2.57 to 3.54). T-tests scores were: Item 1 , $t(13)$-2.28, $p=0.040$; Item 2, $t(13)-2.482, p=0.028$; Item 3, $t(13)-2.482, p=0.028$; Item 4, $t(13)-2.511, p=0.026$. The authors propose that these variations could reflect character development as students' views of their role in the society changed as they participated in the Philanthropy Project. Because the difference between "somewhat likely" and "pretty likely" on the scale may not have been clear to some participants, interpretation of the survey data, however, needs to be with caution.
} 


\section{Table 2}

Satisfaction survey at University B $(\mathrm{n}=14)$

\begin{tabular}{|ll|c|}
\hline$\#$ & Question & $\begin{array}{c}\text { Mean } \\
\text { (s.d.) }\end{array}$ \\
\hline $\begin{array}{l}\text { 1. } \\
\text { The project illustrated some of the practical challenges associated with the real } \\
\text { world. }\end{array}$ & $\begin{array}{c}3.93 \\
(0.73)\end{array}$ \\
\hline $\begin{array}{l}\text { 2. } \\
\text { decision-making when evaluating an organization. }\end{array}$ & $\begin{array}{c}4.14 \\
(0.77)\end{array}$ \\
\hline 3. & The project allowed me to learn about the not-for-profit sector. & 4.14 \\
& $(0.77)$ \\
\hline 4. & Overall, the philanthropy project was a good use of my time. & 4.07 \\
& $(0.83)$ \\
\hline 5. & The instructor should continue to use the project in the future. & 4.21 \\
& $(0.80)$ \\
\hline 6. & I would feel comfortable talking to a client about conducting a financial analysis of a \\
not-for-profit. & 4.00 \\
\hline 7. & The project improved my appreciation of not-for-profit organizations. & $(0.78)$ \\
\hline 8. & The project increased your interest in the not-for-profit sector as a possible career \\
choice. & 4.2 \\
& $(0.70)$ \\
\hline
\end{tabular}

Scale: $1=$ "Strongly Agree," .., 5 = "Strongly Disagree"

\section{Conclusion}

Accounting stakeholders (e.g., the AICPA) and visionaries (e.g., the Pathways Commission) have asked educators to develop future professionals who not only have mastered accounting content, but who have also acquired personal competencies. To accomplish this, the authors present an educational project that uses experiential education that is meant to develop the AICPA (2005) competencies of personal demeanor, decision-making, interaction, and communication skills. In effect, the Philanthropy Project moves the focus of the classroom from a narrow technical approach to a more broad-based one that develops the whole person. Such an 
education might be described as a liberal accounting education, "the cultivation of intellectual skills, development of students' ability to communicate their thoughts effectively, both orally and in writing, with a deep understanding of the ethical and social problems that exist in the society in which they function" (Rama, 1998a, 9).

This paper also demonstrates how a philanthropy-based project can help develop character as students serve the local community. The authors present some preliminary evidence as to how the Philanthropy Project cultivates what we call the five Cs, two of which are more cognitivelybased (viz., conceptual understanding and critical thinking) and three that are more personallybased (viz., community engagement, collaboration and communication, and character development). Lastly, the authors provide a set of resources- guidelines, a timeline of activities, grading rubric, and templates-to increase the likelihood of success in implementing this project in other accounting classes.

The newly conceptualized philanthropy-based education seeks to educate the whole person. As eminent Harvard Professor Howard Gardner stated in Good Work, "It has never been easy to be a professional in both senses of the word 'good,' technically expert and morally responsible" (Barberich \& Gardner, 2001, 1). An education that develops both these capacities, as the Philanthropy Project attempts to do, might be considered education par excellence. 


\section{Acknowledgements}

The paper would not have been possible without the support of many individuals. The authors offer thanks to Roger Grein, philanthropist and CPA, for his inspiration and financial support for the project. Special thanks to the Kentucky and Ohio Campus Compacts for their guidance and assistance in allowing us to bring philanthropy to our campuses. Deepest gratitude is also due to guest editor, Suzanne Lowensohn, and editor-in-chief, David Stout, whose knowledge and assistance made this publication possible. 


\section{References}

Albrecht, W. S., \& Sack, R. J. (2000). Accounting education: Charting the course through a Perilous Future. Accounting Education Series (16). Sarasota, FL: American Accounting Association.

American Institute of Certified Public Accountants (AICPA) Pre-Certification Education Committee. (2005). Core competency framework and educational competency assessment. $<$ http://www.aicpa.org/interestareas/accountingeducation/resources/pages/corecompetency . aspx $>$ Accessed 8.12.12.

American Institute of Certified Public Accountants (AICPA) (2008). The CPA vision project: 2011 and beyond. $<$ http://www.aicpa.org/research/cpahorizons2025/cpavisionproject/downloadabledocumen ts/cpavisionproject_finalreport.pdf $>$ Accessed 8.12.12.

Astin, A. W., \& Sax, L. J. (1998). How undergraduates are affected by service participation. Journal of College Student Development, 39(3), 251-263.

Astin, A. W., Vogelgesang, L. J., Ikeda, E. K., \& Yee, J. A. (2000). How Service Learning affects students. Los Angeles, CA: Higher Education Research Institute, University of California.

Barberich, K., \& Gardner, H. (2001). Good work in business. Good Work Project Report Series, Number 4. Solomon, J., Ed. Cambridge, MA: Harvard University. http://www.goodworkproject.org/wp-content/uploads/2010/10/4-GW-in-Business8_00.pdf. Accessed 11.13,12.

Boss, J. A. (1994). The effect of community service works on the moral development of college ethics students. Journal of Moral Education, 23(2), 183-198.

Bringle, R., \& Hatcher, J. (1995). A service learning curriculum for faculty. Michigan Journal of Community Service Learning, 2, 112-122.

Blanthorne, C., Bhamornsiri, S. \&Guinn, R. E. (2005).Are technical skills still important? The CPA Journal (March). <http://www.nysscpa.org/cpajournal/2005/305/essentials/p64.htm> Accessed 11.12.12.

Carr, J. (1998). Service learning in accounting: A role for VITA tax programs, in Rama, D. V. (Ed.) Learning by Doing: Concepts and Models for Service-Learning in Accounting. Washington, DC: American Association for Higher Education, 101-116.

Chiang, B. (2008). Integrating a service-learning project into managerial accounting courseworkA sharing of implementation experience and lessons learned. Accounting Education: An International Journal, 17(4), 431-445.

Clavert, V., \& Kurji, R. (2012). Service-learning in a managerial accounting course: Developing the "soft" skills. American Journal of Economics and Business Administration, 4(1), 5-12.

Cruz, A. M. (2001). Using service learning to motivate and engage accounting students, Business Education Forum, 56(2), 34-35. 
Davis, T. R. V., \& McLaughlin, L. P. (2009). Finance's Partnering Role (Part 2): Breaking down boundaries: How finance can help business partnering succeed. Strategic Finance (April):46-53.

DeBerg, C. (1998). Service-learning: A free enterprise model for accounting faculty, in Rama, D. V. (Ed.) Learning by Doing: Concepts and Models for Service-Learning in Accounting. Washington, DC: American Association for Higher Education (AAHE), 65-84.

Eyler, J., \& Giles, D. E. (1999). Where's the learning in service-learning? San Francisco, CA: Jossey-Bass Publishers.

Eyler, J., Giles, D., Jr., Stenson, C., \& Gray, C. (2000). At a glance: What we know about the effects of service-learning on college students, faculty, institutions, and communities, 1993-2000. Learn and Serve America National Service-Learning Clearinghouse.

Fontaine, R. (2012). The CMA competency map simplified: Understanding the CMA framework. CMA Magazine, March/April, 21-29.

Francisco, W., Kelly, J. A., \& Parham, A. G. (2003). Skills development in accounting education: Is everyone on the same page? Business Education Forum, 57(4), 28-31.

Giles, D. E., Jr., \& Eyler, J. (1994). The impact of a college community service laboratory on students' personal, social, and cognitive outcomes. Journal of Adolescence, 17(4), 327339.

Gujarathi, M. R., \& McQuade, R. J. (2002). Service-learning in business schools: A case study in an intermediate accounting course. Journal of Education Business, 77(3), 144-150.

Hardie, T., Koster, R., \& Zahaf, M. (2011). Assessing the impacts of community service learning on business and nonbusiness student perceptions and grades. Review of Business Research, 11(1), 163-172.

Kahne, J. E., \& Sporte, S. E. (2008). Developing citizens: The impact of civic learning opportunities on students' commitment to civic participation. American Educational Research Journal, 45(3), 738-766.

Kielsmeir, J. (2011). Service-learning: The time is now. The Prevention Researcher, 18(1), 3-7.

Koehn, D., \& Ueng, J. (2010). Is philanthropy being used by corporate wrongdoers to buy good will? Journal of Management and Governance, 14(1), 1-16.

La Cour, A. \& Kromann, J. (2011). Euphemisms \& hypocrisy in corporate philanthropy. Business Ethics: A European Review, 20(3), 267-279.

Lenk, M. M. (1998). A multi-semester accounting information systems course implementation, in Rama, D. V. (Ed.) Learning by Doing: Concepts and Models for Service-Learning in Accounting. Washington, DC: American Association for Higher Education, 147-156.

Lynn, E., \& Wisely, S. (2006). Four traditions of philanthropy, in Davis, A. and Lynn, S. (Eds.) The Civically Engaged Reader, Chicago, IL: Great Books Foundation. 
Mabry, J. B. (1998). Pedagogical variations and student outcomes in service-learning: How time, contact, and reflection matter. Michigan Journal of Community Service Learning, 5, 3247.

McPhail, K. (2005). Care in the community: Professional ethics and the paradox of pro bono. Accounting Education, 14(2), 213-227.

Martin, S., Neal, M., Kielsmeir, J.C., \& Crossley, A. (2006). The impact of service-learning on transitions to adulthood, growing to greatness. St. Paul: MN, Youth Leadership Council.

Mass, K., \& Liket, K. (2011). Talk the walk: Measuring the impact of strategic philanthropy. Journal of Business Ethics, 100(3), 445-464.

Michenzi, A. R. (1998). Service-learning project in the accounting information systems course: Implementation without the benefit of hindsight, in Rama, D. V. (Ed.) Learning by Doing: Concepts and Models for Service-Learning in Accounting. Washington, DC: American Association for Higher Education, 133-146.

Milani, K. (1998). Tax assistance program provides service-learning at Notre Dame and St Mary's College, in Rama, D. V. (Ed.) Learning by Doing: Concepts and Models for Service-Learning in Accounting. Washington, DC: American Association for Higher Education, 117-124.

Millisor, J., \& Olberding, J. C. (2009). Student philanthropy in colleges and universities. Academic Exchange Quarterly, 13(4), 11-16.

Nishishiba, M., Nelson, H. T., \& Shinn, C. W. (2005). Explicating factors that foster civic engagement among students. Journal of Public Affairs Education, 11(4), 269-285.

Niemotko, T. J. (2003). Restoring Public Trust in Accounting. CPA Journal, 73(10), 20-26.

Oestreich, N., Venable, C., \& Doran, M. (1998). Volunteer income tax assistance and the use of technology, in Rama, D. V. (Ed.) Learning by Doing: Concepts and Models for ServiceLearning in Accounting. Washington, DC: American Association for Higher Education, 125-132.

Olberding, J. C. (2009). "Indirect giving" to nonprofit organizations: An emerging model of student philanthropy. Journal of Public Affairs Education, 15(4), 463-492.Pathways Commission, The. (2012). Charting a national strategy for the next generation of accountants. Sarasota, FL: American Accounting Association. <Available at: www.pathwayscommission.org > Accessed 8.20.12.

Perry, J. L. (2005). Recovering the civic in public affairs education. Journal of Public Affairs Education, 11(4), 265-268.

Porter, M., \& Kramer, M. (2002). The competitive advantage of corporate philanthropy. Harvard Business Review, 80(12), 56-68.

Pringle, L. M. (1998). Expanding the boundaries of accounting education through servicelearning, in Rama, D. V. (Ed.) Learning by Doing: Concepts and Models for Service- 
Learning in Accounting. Washington, DC: American Association for Higher Education, 85-100.

Rama, D. V. (1998a).Service-learning: An active learning approach for accounting education, in Rama, D. V. (Ed.) Learning by Doing: Concepts and Models for Service-Learning in Accounting. Washington, DC: American Association for Higher Education, 3-18.

Rama, D. V. (1998b). Service-learning projects in accounting: Implementation strategies, in Rama, D.V. (Ed.) Learning by Doing: Concepts and Models for Service-Learning in Accounting. Washington, DC: American Association for Higher Education, 203-208.

Ravenscroft, S. P. (1998). Teaching professional accounting ethics with service-learning, in Rama, D. V. (Ed.) Learning by Doing: Concepts and Models for Service-Learning in Accounting. Washington, DC: American Association for Higher Education, 167-190.

Rose, J. M., Rose, A. M., \& Norman, C. S. (2005). A service-learning course in accounting information systems. Journal of Information System, 19(2), 145-172.

Seifert, B., Morris, S. A., \& Bartkus, B. R. (2004). Having, giving and getting: Slack resources, corporate philanthropy, and firm financial performance. Business \& Society, 43(2), 135161.

Smith, V. T. \& O'Loughlin-Brooks, J., (2011). Creating a successful service learning student philanthropy course. St. Petersburg, FL: National Institute on the Teaching of Psychology.

Still, K., \& Clayton, P. R. (2004). Utilizing service-learning in accounting programs. Issues in Accounting Education, 19(4), 469-486.

Stukas, A. A., Snyder, M., \& Clary, E. G. (1999). The effects of "mandatory volunteerism" on intentions to volunteer. Psychological Science, 10(1), 59-65.

Strupeck, C. D., \& Whitten, D. (2004). Accounting service-learning experiences and the IRS volunteer income tax assistance programme: A teaching note. Accounting Education: An International Journal, 13(1), 101-112.

Tschopp, D. J. (2004). The Seneca Babcock business plan: A case study in using service learning to meet the AICPA core competencies. Journal of Education for Business, 79(50), 261266.

Tucker, M. L., \& McCarthy, A. M. (1998). Student attitudes toward service-learning: Implications for implementation. Journal of Management Education, 23(5), 554-573.

Vega, G. (2007). Teaing business ethics through service learning metaprojects. Journal of Management Education, 31(5), 647-678.

Waterman, A. (1997). The role of student characteristics in service-learning, in Waterman, A. (Ed.), Service-Learning: Applications form the Research. Hillsdale, NJ: Lawrence Erlbaum Associates. 
Wilkenson, I. A. G., Doepker, G. M., \& Morbitt, D. (2012). Bringing service-learning to scale in an undergraduate reading foundations course: A quasi-experimental study. Journal of Excellence in College Teaching, 23(2), 93-122.

Wiley Periodicals, Inc. (2011). Corporate Philanthropy Report, 26(8), 1-3.

Woolley, J. W. (1998). Service-learning in capstone course, in Rama, D. V. (Ed.) Learning by Doing: Concepts and Models for Service-Learning in Accounting.). Washington, DC: American Association for Higher Education, 157-166.

Yates, M., \& Youniss, J. (1996). A developmental perspective on community service in adolescence. Social Development, 5(1), 85-111.

Zamora, V. (2012). Using a social enterprise service-learning strategy in an introductory management accounting course. Issues in Accounting Education, 27(1), 187-226. 


\section{Appendix A}

\section{Timeline of Activities}

It is important for faculty to adopt the schedule with their course objectives. This schedule provides a description of activities with target deadlines.

Week 1 Discuss the Philanthropy Project and needs for our community. Form community boards.

Week 2 Create a list of not-for-profit organizations as possible candidates for the grants. Begin to work on profiles for these organizations. Find articles on the local charities under investigation. Create a wiki for each agency nominate for the grant (see wiki guidelines for required information).

Week 3 Create a list of agencies to invite in the RFP process. Contact agencies and invite them to submit a proposal for the grant. Determine what should be in the request for funding.

Week 4 Send out invitations to agencies to submit a proposal.

Week 6 Organizations' requests for funding are due this week.

Week $7 \quad$ Post portions of the proposals to the wikis. Students read the various proposals before class. Groups will be assigned certain proposals to look at in-depth. In this class, students will break into groups to conduct an in-depth analysis of particular charities. Then the groups will get together as a class to decide which charities to invite the following week.

Week 8 Ask selected agencies to give a 20-minute presentation to: (1) describe the agency's mission and programs; (2) explain how they will spend the awarded funds; and (3) $Q$ and $A$ session.

Week 9 Deliberate about which organizations to award funds to.

Week 10 Hold awards ceremony and reception. 


\section{Appendix B}

\section{Grading Rubric}

\section{Philanthropy Group Project}

Project Summary: Your team will identify an NFP organization to invite to submit a grant proposal. Your team will collect and report on pertinent information on a shared digital platform (i.e. wiki). Your team will also score the grant proposals and invite NFP executives to class for a presentation.

\begin{tabular}{|l|l|}
\hline $\begin{array}{l}\text { Project } \\
\text { Goals: }\end{array}$ & At the conclusion of this project, you will be able to: \\
- & Research NFP organizations to find and understand pertinent information \\
about its mission, key donors, objectives, financial statements, and budgets. \\
- \\
See the relation between what you are learning in class to what you are \\
seeing in real world. \\
- Gain an insight on how accounting is practiced in an NFP. \\
- Improve your skills in the following areas: \\
1. Communication \\
2. Conducting research \\
3. Time management \\
4. Project management \\
5. Teamwork
\end{tabular}

\section{Course Project Grading Rubric:}

\begin{tabular}{|l|l|}
\hline Parts: & Guidelines: \\
\hline $\begin{array}{l}\text { 1- Identification, history, } \\
\text { mission, needs assessment } \\
\text { (10 points) }\end{array}$ & $\begin{array}{l}\text { Provide link to the website and contact information } \\
\text { Depending on the organization, most of this information is } \\
\text { electronically available. }\end{array}$ \\
\hline $\begin{array}{l}\text { 2- Key donors } \\
\text { (10 points) }\end{array}$ & Identify key donors for the organization \\
\hline $\begin{array}{l}\text { 3- Financial Statements } \\
\text { (10 points) }\end{array}$ & $\begin{array}{l}\text { Collect and post a minimum of two years financial statements (or } \\
\text { available financial information) }\end{array}$ \\
\hline $\begin{array}{l}\text { 4- Construction of a shared } \\
\text { digital platform (e.g. Wiki) }\end{array}$ & $\begin{array}{l}\text { Develop a shared digital platform (i.e., wiki) with the following } \\
\text { characteristics (as required on Template 1): } \\
\text { Reader friendly } \\
\text { Currency } \\
\text { Clarity } \\
\text { Organization of content } \\
\text { Comprehensiveness }\end{array}$ \\
\hline
\end{tabular}




\begin{tabular}{|c|c|}
\hline $\begin{array}{l}\text { 5- Communication with the } \\
\text { NFP ( } 20 \text { points) }\end{array}$ & $\begin{array}{l}\text { Initiating contact with the organization } \\
\text { Explaining the project } \\
\text { Communicating deadlines } \\
\text { Corresponding with the NFP organization (via emails) }\end{array}$ \\
\hline $\begin{array}{l}\text { 6- Development of short } \\
\text { list of organizations } \\
\text { (10 points) }\end{array}$ & $\begin{array}{l}\text { Each team will submit two organizations to be considered on the } \\
\text { short list }\end{array}$ \\
\hline $\begin{array}{l}\text { 7- Narrow the list with } \\
\text { justifications who to invite } \\
\text { to submit the grant (some } \\
\text { agencies will be taken off } \\
\text { the list at this point) } \\
\text { ( } 20 \text { points) }\end{array}$ & $\begin{array}{l}\text { The list is narrowed based on the followings: } \\
\text { Personal preferences } \\
\text { Needs of the community } \\
\text { Size of the organization } \\
\text { Reputation of the organization }\end{array}$ \\
\hline $\begin{array}{l}8 \text { - Review of proposals } \\
\text { With the rank order and } \\
\text { invitation sent to highest } \\
\text { rankings } \\
\text { (20 points) }\end{array}$ & Template 4 \\
\hline $\begin{array}{l}\text { 9- Evaluation of } \\
\text { presentations } \\
\text { (20 points) }\end{array}$ & Template 5 \\
\hline $\begin{array}{l}\text { 10- Final discussion to } \\
\text { decide on the winners } \\
\text { (10 points) }\end{array}$ & $\begin{array}{l}\text { Teams will vote and rank order the participants } \\
\text { Participation in class discussions } \\
\text { Persuasion skills } \\
\text { Group decision making }\end{array}$ \\
\hline $\begin{array}{l}\text { 11- Reflection of your } \\
\text { learning from this project } \\
\text { ( } 20 \text { points) }\end{array}$ & $\begin{array}{l}\text { Template } 8 \\
\text { Quality of student response }\end{array}$ \\
\hline $\begin{array}{l}12-\text { Teamwork } \\
\text { Contribution } \\
\text { (10 points) }\end{array}$ & $\begin{array}{l}\text { Template } 8 \\
\text { Based on other team members' information }\end{array}$ \\
\hline Total points (200 points) & \\
\hline
\end{tabular}




\section{Appendix C - Supporting Templates}

\section{Template 1: Collaborative Website Development}

Here is some possible information to include in your wiki agency profiles:

-What is the history of the organization?

-What is the mission \& purpose of the organization?

-What services does this agency provide?

-What audience does the agency cater to, i.e., demographic information? How does this agency manage the diversity of the public it serves?

-What are the agency's sources of revenues? How does the agency recruit donors?

- Explain the structure of the agency/its organizational design: \# of full and part-time employees $\& \#$ of volunteers used $\&$ number of volunteer hours per year. How does the agency recruit volunteers?

-What are the trends this agency follows? Have there been any recent changes in their environment that have caused the agency to change or are areas of concern for them, especially in the area of their products/services provided and their processes.

-What are the leadership challenges of running this agency?

- How does the agency motivate its employees and volunteers?

-What are some examples of financial and non-financial measurements the agency uses to gauge it performance? How does the agency measure its impact on the community in the short-term and in the long-term as well?

- Are there any press releases for the organization - positive or negative?

- Add any pictures/graphics that might help us understand the agency better.

- Add the web link to the agency and financial statements.

-What are some of your own reflection about what you've discovered about this agency? 


\section{Template 2: Requests for Proposals \\ Application Form for Funding (not to exceed \$2,000.00)}

RPF must be received by no later than (date) as a Word Document attachment to name@university.edu

Name of Organization:

Contact Person:

Title:

Mailing Address:

Email address:

Telephone number: Fax number: Federal Tax I.D \#:

Name and Title of Authorized Agency

Representative:

Signature of Authorized Agency Representative:

Please briefly answer the following questions. (Maximum of 5 pages excluding appendix) Please make sure you answer every question. Students will be evaluating your application and will invite finalists to complete a 20 -minute presentation to our class on Date.

1. Describe your proposed activities and/or the project(s) you hope to accomplish if you receive this grant.

2. Indicate how this funding will allow you to enhance your current program. For instance tell us the number of people (i.e., children) that will benefit from this grant.

3. What are the specific outcomes or goals for your project?

4. Give evidence of your efficiency. Efficiency in this context means - what percentage of your budget goes directly to support your programs? If affiliated with a national organization, what percentage of your funds stays local?

5. What is your main source of funding? What percentage of your total funding is provided by your board members and/or employees?

6. How much money are you requesting and how will it be spent (please be specific)? Submit a budget with a narrative. Will your organization commit any matching funds or in-kind donations to the project (not a requirement)?

7. Briefly tell us why your organization should be awarded a grant. Articulate your passion for your mission.

8. Attach a copy of your most current annual report or financial statements. Also attach a copy of IRS Letter of Exemption or verification of 501 c (3) standing.

9. Feel free to include any additional information that you think might help us in our decisionmaking process. 


\section{Template 3: Invitation Letter}

DATE:

TO: Executive Director

FROM:

RE: Student Philanthropy Project

Three students in my accounting course have identified your not-for-profit organization as one they would like to learn more about. The students are participating in the Student Philanthropy Project, through which they will be awarding from $\mathbf{\$ 1 , 0 0 0}-\mathbf{\$ 2 , 0 0 0}$ to one or more local not-forprofit 501 (c) (3) organizations.

With this project, students learn about community needs and the efforts of local organizations to meet those needs. They have already prepared an essay about your organization which is posted on our class wiki (a collaborative website) for all of the students to read.

My students would like you to complete a Request for Funding Proposals (RFPs). This quarter, we may have 6 - 9 potential proposals to review. Upon the review of all the proposals, the class will narrow the pool down to 3 - 4 agencies to present to the class. This is a competitive process.

As students participate in this process, they gain decision-making skills as well as civic responsibility - all while learning the subject matter of accounting as they look at your financial statements and budgets.

We appreciate the time you will take to fill out the RFP. Here are important dates:

[date]- Proposal is due via email.

[date]- Invitations will be sent to $3-4$ agencies requesting a presentation on campus.

[date]- Organizations will present to the class.

[date]-Celebration awards ceremony where funding is given to the organizations.

We hope this will be a good experience for you. Please feel free to contact me, if you have any questions about the Student Philanthropy Project. Our RFP guidelines are attached.

Thank you for considering our request to work with you. 


\section{Template 4: Scoring Rubric for Proposals}

Organization Name:

Reviewer Name:

Total Score:

\begin{tabular}{|c|c|c|c|}
\hline Selection Criteria 1: Program Narrative (10 pts.) & Pg. \# & Points & Notes \\
\hline a) Statement of project (Q1)* & & & \\
\hline $\begin{array}{l}\text { b) Why should the applicant be awarded the grant } \\
\text { (Q7) }\end{array}$ & & & \\
\hline Selection Criteria 2: Funding (10 pts.) & & & \\
\hline a) Efficiency ratios (Q4) & & & \\
\hline b) Funding sources (Q5) & & & \\
\hline $\begin{array}{l}\text { Selection Criteria 3: Goals and Outcomes (10 } \\
\text { pts.) }\end{array}$ & & & \\
\hline a) How many will benefit (Q2) & & & \\
\hline b) Specific goals and outcomes (Q3) & & & \\
\hline $\begin{array}{l}\text { Selection Criteria 4: Financial Stewardship (10 } \\
\text { pts.) }\end{array}$ & & & \\
\hline a) Budget evaluation (Q6) & & & \\
\hline b) Evaluation of financial statements (Q8) & & & \\
\hline Selection Criteria 5: Overall (10 pts.) & & & \\
\hline $\begin{array}{l}\text { a) Did the applicant make a good case for the } \\
\text { use/need for the grant? }\end{array}$ & & & \\
\hline $\begin{array}{l}\text { b) Do you think the cause is worthy to be awarded } \\
\text { the grant? }\end{array}$ & & & \\
\hline
\end{tabular}

*Note: The references to (Q1) or (Q2), for example, points to the question number answered by agencies in Template 2 . 
Template 4: Scoring Summary for Proposals

Name of Applicant:

Reviewer Name:

Points

Criteria 1: Program Narrative (\# 10 POINTS)

Criteria 2: $\quad$ Funding (\# 10 POINTS)

Criteria 3: Goals and Outcomes (\# 10 POINTS)

Criteria 4: Financial Stewardship (\# 10 POINTS)

Criteria 5: Overall (\# 10 POINTS)

TOTAL:

1) PROGRAM NARRATIVE

STRENGTHS:

WEAKNESSES:

2) FUNDING MANAGEMENT

STRENGTHS:

WEAKNESSES:

3) GOALS AND OUTCOMES

STRENGTHS:

WEAKNESSES:

4) FINANCIAL STEWARDSHIP

STRENGTHS:

WEAKNESSES:

5) OVERALL

STRENGTHS:

WEAKNESSES:

Reviewer Recommendation

$\square$ Recommend for funding

$\square$ Recommend for funding with specific changes to proposal as listed below:

$\square$ Do not recommend for funding 


\section{Template 5: Scoring of NFP Executive Presentation}

\section{Organization Name:}

\begin{tabular}{|l|l|}
\hline EVALUATION - Criteria for Scoring & SCORE \\
\hline $\begin{array}{l}\text { CONTENT: Evaluate what the speaker is saying - Does the information } \\
\text { make sense and did speaker follow the required guidelines (20 points) }\end{array}$ & \\
\hline $\begin{array}{l}\text { COMMUNICATION: Use of visual aids - Are they appropriate and used } \\
\text { properly (i.e., as “aids", not the whole show)? (10 points) }\end{array}$ & \\
\hline $\begin{array}{l}\text { CLARITY: Flow of the presentation - Is it understandable? Does it progress } \\
\text { logically? Is the speaker making the appropriate arguments? (10 points) }\end{array}$ & \\
\hline $\begin{array}{l}\text { CARRIAGE: Speaker's appearance, gestures, strength of voice, eye contact, } \\
\text { confidence, etc. (10 points) }\end{array}$ & \\
\hline $\begin{array}{l}\text { RESPONSIVENESS: Speaker's ability to answer questions or respond to } \\
\text { comments. (10 points) }\end{array}$ & Total (60 points) \\
\hline
\end{tabular}




\section{Template 6: Award Letter}

DATE:

TO: $\quad$ Organization Director

\section{FROM:}

RE: $\quad$ Student Philanthropy project

Congratulations! The students involved in the Student Philanthropy Project at B University have decided to award your organization a grant of $\mathbf{\$ 1 , 0 0 0}$ to fund the project outlined in your proposal. This project is possible with the generous funding of an anonymous donor.

Please know that the class was impressed by the level of commitment your organization has to the community and the quality of your funding proposal. The students especially liked the fact that you helped families become self-sufficient. The students appreciated the extra time you took to develop a chart and metrics regarding your success. Lastly, the students appreciated your contribution to the local economy.

An awards ceremony has been scheduled [location] on [date and time]. Please send a representative to accept this award on behalf of your agency. We ask that this representative and any other interested parties arrive by no later than [time]. Please RSVP by no later than [date] so that we know the expected number of guests.

We would like to remind you that all participating agencies (funded and unfunded) are required to complete an online survey at the end of the quarter to measure their satisfaction with the project and process. Also, a campus liaison will visit grant recipients to evaluate how funds were used. If you have questions please contact Professor X at e-mail.

Again, congratulations and thank you for participating in the Accounting Philanthropy Project. It has been a pleasure to learn about and meet people from your agency, and we look forward to honoring your agency's commitment at the upcoming awards ceremony. 


\section{Template 7: Rejection Letter}

DATE:

TO: $\quad$ Organization Director

\section{FROM:}

RE: $\quad$ Student Philanthropy project

We regret to inform you that your organization was not selected to receive the Student Philanthropy Project Grant. Please know that this was not an easy decision for the class to make. We recognize the importance of what you do and wish we had more funds to distribute.

This collected decision in no way diminishes the importance of what you and your dedicated staff do. All the not-for-profit organizations the class considered showed a high level of commitment to their communities, and we are grateful to have learned about your organization. We thank you for the time you spent working with us on this project, allowing us to meet and learn about your organization and its excellent programs.

Please be advised that you will soon receive a request from evaluators to fill out an online survey to gauge your level of satisfaction with the project and process. If you have any questions please contact $\underline{\text { Professor } \mathrm{X}}$ at email.

Again, we thank you for helping to educate our students about your mission, vision, and area of need. 


\section{Template 8: Student Reflection Paper}

Please answer the following questions pertaining to the Philanthropy Project:

1) What concepts, principles, or ideas did you learn from the Philanthropy Project?

2) What did the Philanthropy Project teach you about financial decision-making?

3) What was the most interesting thing you learned from participating in the Philanthropy Project?

4) What were the determining factors in your selection of one agency over another in awarding funding?

5) Compare and contrast what you learned from the organizations that presented in class?

6) How has the Philanthropy Project changed you?

\section{Team Member Evaluation}

Rank yourself and your team members' contribution to the project. You need to justify the ranking and how each team member contributed to the overall project.

\begin{tabular}{|l|l|l|}
\hline Team: & \% Contribution & \\
\hline Your name: & & \\
\hline Member name: & & \\
\hline Member name: & & \\
\hline Member name: & & \\
& & \\
\hline
\end{tabular}

